\title{
Öğretmenlerin Örgütsel Adalet Algıları ve Örgütsel Sessizlik Düzeyleri Arasındaki İlişki*
}

\author{
Yavuz ÜNLÜ ${ }^{* *}$ Mehmet Ali HAMEDOĞLU ${ }^{* * *}$ Erkan YAMAN ${ }^{* * * *}$ \\ Öz
}

Bu çalışmanın amacı öğretmenlerin örgütsel adalet algıları ve örgütsel sessizlik düzeyleri arasındaki ilişkiyi belirlemektir. Araştırma 2014-2015 yıllarında Balıkesir ili Bandırma ilçesinde görev yapan 350 öğretmeni kapsamaktadır. Araştırmada Niehoff ve Moorman (1993) tarafından geliştirilen ve Gürpınar (2006) tarafından tarafından Türkçeye uyarlanan örgütsel adalet ölçeği ve Van Dyne, Ang ve Botero (2003) tarafından geliştirilen ve Taşkıran (2011) tarafından uyarlanan örgütsel sessizlik ölçeği kullanılmıştır. Araştırma ilişkisel tarama modelinde gerçekleştirilmiştir. Ölçme aracından elde edilen verilerin çözümlenmesinde SPSS 20.0 paket programı kullanılmıştır. Araştırma sonuçları, öğretmenlerin dağıtımsal, işlemsel ve etkileşimsel adalet algıları ile savunmacı sessizlik düzeyleri arasında negatif yönlü, korumacı ve kabullenici sessizlik düzeyleri ile pozitif yönlü bir ilişki olduğunu göstermiştir. Araştırma bulgularına dayalı olarak okul yöneticilerinin adil, demokratik ve sessizliği önleyici bir yönetim tarzı benimsemeleri önerilmiştir.

Anahtar Kelimeler: Örgütsel Adalet, Örgütsel Sessizlik, Öğretmen.

\section{The Relationship Between Perceived Organizatinal Justice and Organizational Silence Level of Teachers}

\begin{abstract}
The aim of this study is to determine the relationship between perceived organizational justice and level of organizational silence of teachers. The current study's sample was composed 350 volunteer teacher who are working in Bandirma province of Balıkesir city. In this study, the scale for determining perceived organizational justice developed by Niehoff and Moorman (1993) and adapted by Gürpınar (2006) and the scale for measuring organizational silence level developed by Van Dyne, Ang and Botero (2003) and adapted by Taşkıran (2011) are used. This research is done by using relational survey model. In the analysis of data which procured from scales SPSS 20.0 sofware were utilized. Results of the research showed that teachers distributive, procedural and interactional justice perceptions have negative relation with defensive silence, while having positive relation with prosocial silence and acquiescent silence. Based on the findings, It is recommended to the school principals to adopt a just, democratic and silence preventing management style.
\end{abstract}

Keywords: Organizational Justice, Organizational Silence, Teacher.

\footnotetext{
* Bu çalışma, M.Ali Hemedoğlu ve Erkan Yaman'ın danışmanı olduğu yüksek lisans tezi bulgularını kısmen yansıtmaktadır.

** Sakarya Üniversitesi, Eğitim Bilimleri Enstitüsü, Eğitim Bilimleri Bölümü, yavuz.unlu@ogr.sakarya.edu.tr .

*** Yrd.Doç Dr, Sakarya Üniversitesi, Eğitim Bilimleri Enstitüsü, Eğitim Bilimleri Bölümü, mhamed@sakarya.edu.tr

${ }^{* * * *}$ Doç. Dr. Sakarya Üniversitesi, Eğitim Bilimleri Enstitüsü, Eğitim Bilimleri Bölümü, eyaman@sakarya.edu.tr
} 


\section{GİRIŞ}

Sosyal bilimciler, iş görenlerin adalete ilişkin algılarının örgütsel çıtılar açısından önemli olduğunu belirtmişlerdir. Bu bağlamda, "sosyal adalet" kavramını genel olarak irdeleyen kuramların (Hakkaniyet Kuramı, Adaleti Yarg1lama Modeli) örgütlere uyarlanmasını ve örgüt içindeki ilişkilere bağlı olarak ortaya çıkan kazanımların (output) adil dağıtımını açıklayan 'örgütsel adalet' (organizational justice) kavramını geliştirmişlerdir (Greenberg, 1990a). Örgütsel adaletle ilgili yapılan araştırmalar 30 yılı aşkın bir süredir devam etmektedir. Örgütsel adalet, işyerinde adil davranılıp davranılmadığına iş görenlerin nasıl karar verdiğiyle ve bu kararların işle ilgili diğer değişkenleri nasıl etkilediğiyle ilgili bir kavramdır (Moorman, 1991). Greenberg (1987; 1990b), bu kavramı, kazanımların (dağıtımsal adalet), süreçlerin (işlemsel adalet) ve bireyler arası ilişkilerin (etkileşimsel adalet) adilliğine dayalı olarak üç boyutta incelemiştir. Son yapılan araştırmalar dağıtımsal adaletin iş görenlerin kararın sonucundan duydukları tatmine etkisinin işlemsel adaletin etkisinden daha önemli olduğunu gösterirken, işlemsel adaletin ise iş görenlerin kararı verenleri değerlendirmesinde dağıtımsal adaletten daha önemli olduğunu göstermiştir. Üçüncü akım ise dağıtımsal ve işlemsel adaletin iş görenlerin kararlara olan tepkilerine etkileşimsel etkisini değerlendirmektedir (Brockner ve Siegel, 1996).

Dağıtımsal adalet, iş görenlerin elde ettikleri kazanımların, ödüllerin adil dağıtılıp dağıtılmadığına ilişkin algılamalarını ifade etmektedir. Farklı bir ifadeyle dağıtımsal adalet, iş görenlerin kazanımların, sergilenen performansa göre doğru ve gerçekçi olarak değerlendirilip değerlendiril-mediğine ilişkin algılamalardır (Folger ve Cropanzano,1998). İşlemsel adalet, kazanımların dağıtımına ilişkin kararla- rın alınmasında kullanılan işlemlerin yani dağıtım sürecinin adilliğidir.

Adil işlem, bir karar verilirken kullanılan işlemin adil olmasinı ifade eder (Folger ve Cropanzano, 1998; Moorman, 1991; Erdoğan, Kraimer ve Liden, 2001). Genel bir tanımlamayla bir örgüt içinde ödüllerin nasıl dağıtıldığıyla ilgilidir. Başka bir deyişle iş görenlerin gösterdikleri performans karşısında aldıkları ödüllerin neye göre ve nasıl belirlendiğini, ödüllerin dağılımında kullanılan karar alma süreçlerinin ve işlemlerin iş görenlerce ne kadar adil olarak algılandığını açıklayan bir kavramdır (Folger, 1987; Konovsky, 2000). Kısaca işlemsel adalet, karar vermede doğru süreçlerin algılanması ile ilgilidir. İşlemlere ilişkin adalet algıları, iş görenlere kendilerini etkileyen kararlarda söz hakkı veya kontrol verilmesiyle ilişkilidir (Alexander ve Ruderman, 1987). İş yerinde kuralların adil olması anlamına gelen işlemsel adaletin sağlanması, iş görenlerin kendilerine adil davranıldığını hissetmeleri için yeterli değildir (Greenberg, 1990b). Uygulama sürecinde yaşanan bireyler arası ilişki işin içine girmektedir. Bies ve Moag (1986), bu boyutu etkileşim adaleti olarak adlandırmıştır. Bies (1987), yaptığı bir araştırmada, dürüstlük, nezaket, düzenli bilgi alışverişinde bulunma, kişi haklarına saygı gösterme ve birbirini dinleme gibi, kişiler arası tavırların, biçimsel işlemlere oranla daha fazla önem verilen kriterler olduğunu ortaya koymuştur.

Adalete ilişkin çalışmalarda, adaletin organizas-yonlarda önemli bir rol oynadığına ve çalışanların inanç, tutum, davranış ve hislerini etkileyebilme gücüne vurgu yapmişlardır (Bos, 2001). Buna ilaveten, çalışanlar organizasyonlarında adil olmayan davranışlarla karşılaştıklarında, organizas-yon için önemsiz olduklarını hissetmeye başlarlar ve karşılaştıkları problemlerde sessiz kalmayı tercih ederler (Dabbagh, Esfahani ve Shahin, 2012). 
Hischrman'a (1970) göre sessizlik, çalışanın işinde doyumsuzluğa verdiği bir yanıttır. Bu sessizlik sonucu, örgütler çalışanların yenilikçi fikirlerinden yararlanamamakta ve önemli bir gelişme fırsatını kaçırmış olmaktadırlar. Brinsfield'a (2009) göre çalışanlar örgütsel amaç ya da süreçlere ilişkin ümitsizlik duygusuna kapıldıklarında ve hiçbir şeyi değiştiremeyeceklerine inandıklarında işleriyle ilgili doyumsuzluk yaşamakta ve sessizleşmektedirler.

Sessizlik, çalışanların bilinçli olarak örgütsel sorun ve konular hakkındaki fikir ve endişelerini seslendirmemeleri olarak tanımlanmaktadir. (Morrison ve Milliken, 2000; Johannesen, 1974). Ryan ve Oestreich'e (1991) göre araştırmalarda katılımcıların örgütle ilgili konuları dile getir-memelerinin en yaygın iki nedeni; olumsuz yansımaya maruz kalmamak ve sorunları dile getirmenin bir değişiklik yaratmayacağına inanmaktır.

Bendersky'e (2005:239) göre örgütsel sessizlik ortamı oluştuğunda, örgüt açısından değişime direnç ve değişime yavaş uyum gösterme davranışı ortaya çıkmaktadır. Sorun ve konulara ilişkin açıkça konuşmama kararı yani 'sessizlik' örgütsel öğrenmeyi engellediği, örgütsel değişim ve gelişime engel oluşturduğu gibi, örgüt içinde farklı düşüncelerin ortaya çıkmasını azaltarak yenilikçiliği ve yaratıcıllı̆̆ engellemektedir (Morrison ve Milliken, 2000; Milliken ve Morrison, 2003)

Sessizliği haksızlığa bir tepki olarak ele alan Pinder ve Harlos (2001) ise iş gören sessizliğini; değişimi etkileyebilme/düzeltebilme yeteneğinde olduğu algılanan insanlara, örgütsel durumlara ilişkin konularda, kişinin davranışsal, bilişsel ve/veya duygusal değerlendirmeleri hakkındaki samimi düşüncelerini esirgemesi olarak tanımlamaktadırlar.

Van Dyne, Ang ve Botero (2003), çalışan sessizliğinin arkasında yatan niyetlere göre üç temel türü olduğunu ileri sürmüşlerdir. Bunlar; kabullenici (boyun eğici) sessizlik, korunmacı (savunma amaçlı) sessizlik ve korumacı (örgüt yararını gözeten) sessizliktir.

Van Dyne, ve diğerlerine (2003) göre bireylerin sessiz kalma davranışında bulunmaları, genellikle diğer bireyler tarafından aktif olarak iletişim kurmaması şeklinde görülebilir. Ancak, kabullenici sessizlik gösteren bir bireyden söz ettiğimizde, bireyin durumla ya da olayla ilgili bilgisi, görüşü veya söyleyecekleri olmasına karşın, kendi isteğiyle bu görüşlerini açıklamamayı tercih etmesi kabul edilmelidir.

Van Dyne ve diğerlerine (2003) göre korunma amaçlı sessizlik, kendini dış tehditlerden koruma amacıyla korkuya dayalı olarak ilgili fikir, bilgi ve görüşlerin diğerlerinden esirgenmesi biçiminde tanımlanabilir (Akt. Durak, 2012:56). Pinder ve Harlos (2001) korumac1 sessizliği, bireyin kişisel olarak açıkça konuşmanın olası sonuçlarından korkmasından dolayı kasıtlı olarak sessiz kalmayı tercih etmesi olarak ifade etmektedir (Akt. Taşkıran, 2011). Üçüncü sessizlik tür olarak korumacı sessizlik ise Dyne, Ang ve Botero (2003) tarafından geliştirilmiş ve yönetim yazınına eklenmiştir (Taşkıran, 2011). Bazı yazarlara göre koruma amaçlı sessizlik özgeci davranışı içermektedir. Özgeci davranış, herhangi bir biçimde karşılık veya ödül beklentisi olmaksızın bir başkasına yardım etme anlamına gelmektedir (Karacaoğlu ve Cingöz 2008). Dolayısıyla koruma amaçlı sessizlik davranışı, başkaları için yapılan, önceden düşünülmüş bilinçli ve isteğe bağlı bir davranıştır. Bu tür sessizlik davranışını gösteren iş görenler, örneğin çalışan veya grup içindeki kaynaşma ve uzlaşmanın sürdürülmesi uğruna muhalif görüşlerini açıkla-mamayı tercih edebilir. Çalışan, arkadaşını koruma adına, onun işteki yetersizliği konusunda sessiz kalmayı tercih edebilir. Ya da başka bir örnekle, çalışan örgütün aleyhine kullanılacak bir bilgiyi, örgü- 
tü korumak amacıyla dışarıya vermeyebilir (Taşkıran, 2011).

Gerek örgütler gerekse çalışanlar açısından artan önemine rağmen, örgütsel sessizlik konusunun örgütsel davranış ve yönetim literatüründe yeterince incelenmediği görülmektedir (Tangirala ve Ramanujam, 2008). Son yıllarda sessizliğin, birey-lerin konuyla ilgili fikirlerinin olmaması ya da söyleyecek bir şeylerinin bulunmaması ötesinde, içerisinde derin ve gizli anlamlar barındıran bir olgu olabileceği düşüncesi yaygın olarak kabul görmeye başlamıştır (Brinsfield vd., 2009). Eğer çalışanlar sessiz kalarak örgütlerine ya da yöneticilerine bir mesaj veriyorlarsa, bu mesajın anlamlandırılması gerekmektedir, çünkü bu mesajların arka planında çalışanların tutumlarını/davranışlarını ya da iş çıktı-larını etkileyebilecek potansiyel riskler mevcuttur (Özdemir ve Uğur, 2013).

Alan yazında, örgütlerde çalışanlar açısından adalet algısının sonuçları ile bu sonuçlardan bir tanesi olan sessizliğin çalışan üzerindeki etkileri artarak bilimsel çalışmalara konu olmaya başlamıştır. Fakat yapılan taramada eğitim örgütlerinin en önemli çalışanlarından öğretmenlerin adalet algıları ve sessizlik düzeyleri bağımsız olarak ve farklı değiş-kenler bağlamında araştırılmasına rağmen iki değiş-kenin birlikte incelenmesi birkaç çalışma ile sınırlı kalmıştır. Bu açıdan öğretmenlerin örgütsel adalet algıları ve sessizlik davranışlarının incelenmesinin literatüre katkı yapacağı düşünülmektedir.

\subsection{Problem Cümlesi}

Öğretmenlerin örgütsel adalet algıları ile örgütsel sessizlik düzeyleri arasında nasıl bir ilişki vardir?

\subsection{Alt Poblemler}

Araştırmanın ana sorusu irdelenirken, aşağıdaki alt problemlere de cevap aranacaktır.
1. Öğretmenlerin örgütsel adalet algıları ve örgütsel sessizlikleri ne düzeydedir?

2. Öğretmenlerin örgütsel adalet algıları ve sessizlik düzeyleri cinsiyet, yaş, görev yapılan okul ve çalıştıkları kurumlarda algıladıkları yönetim tarzı değişkenlerine göre farklılaşmakta midir?

\section{YÖNTEM}

\subsection{Araştırmanın Amacı}

$\mathrm{Bu}$ çalışmanın amacı öğretmenlerin örgütsel adalet algılarını, örgütsel sessizlik düzeylerini ve bu iki önemli husus arasındaki ilişkileri ortaya koymaktır.

Araştırmanın bulgularının eğitim sisteminin en önemli aktörlerinden birisi olan öğretmenlerin mevcut adalet algılarını ve bu duruma tepki olarak geliştirilen sessizlik davranışlarının düzeyini ortaya koyarak, eğitim yöneticilerinde farkındalık yarat-ması beklenmekte ve mevcut durumu ortaya koyması ve alınması gereken önlemlerle ilgili çalış-malara 1şık tutması açısından önem taşımaktadır.

\subsection{Araştırmanın Modeli}

$\mathrm{Bu}$ çalışma ilişkisel tarama modelinde gerçekleştirilmiştir. İlişkisel tarama modelleri iki ve daha çok sayıdaki değişken arasında birlikte değişim varlığını veya derecesini belirlemeyi amaçlayan araştırma modelleridir. İlişkisel tarama modeli gerçek bir neden sonuç ilişkisi vermemekle birlikte bir değişkendeki durumun bilinmesi hâlinde ötekinin kestirilmesine olanak sağlamaktadır (Karasar, 2006).

\section{3 Örneklem Grubu}

Bu çalışmanın örneklem gurubunu araştırmaya gönüllü olarak katılmış Balıkesir İli Bandırma İlçesinde görev yapan 140 erkek ve 210 kadın 
olmak üzere toplam 350 ilköğretim ve ortaöğretim öğretmeni oluşturmaktadır.

\subsection{Veri Toplama Araçları}

Öğretmenlerin örgütsel adalet algıları Niehoff ve Moorman (1993) tarafından geliştirilen ve Gürpınar (2006) tarafından Türkçeye uyarlanan ölçek ile ölçülmüştür. Örgütsel adalet ölçeğinin orijinal formu 20 maddeden ve 3 alt boyuttan oluşmaktadır. Bu alt boyutlar dağıtımsal adalet (5 madde), işlemsel adalet (6 madde) ve etkileşimsel adalettir (9 madde).

Ölçeğin uygulanması sonrası Cronbach Alpha katsayısı tüm ölçek için .95, alt boyutlardan dağıtımsal adalet için .79, işlemsel adalet için .92 ve etkileşimsel adalet için .97 olarak bulunmuştur.

Öğretmenlerin örgütsel sessizlik düzeyleri Van Dyne ve diğerleri (2003) tarafından geliştirilen ve Taşkıran (2011) tarafından Türkçeye uyarlanan ölçek ile ölçülmüştür. Örgütsel sessizlik ölçeğinin orijinal formu 15 maddeden ve 3 alt boyuttan oluşmaktadır. Bu alt boyutlar kabullenici sessizlik (5 madde), savunmacı sessizlik (5 madde) ve korumacı sessizliktir (5 madde).

$\mathrm{Bu}$ araştırmada aynı ölçek için uygulanan güvenirlik analizi sonucunda Cronbach Alpha iç tutarlılık katsayısı ölçeğin tamamında .81, kabullenici sessizlik boyutunda .86, savunmacı sessizlik boyutunda .90 ve korumacı sessizlik boyutunda .81 olarak çıkmıştır.

\subsection{Verilerin Analizi}

Araştırma kapsamına alınan örneklemde toplamda 350 adet ölçek formundan elde edilen veri ve bilgiler SPSS 20.0 (Statistical For Social Sciences ) for Windows istatistik paket programı aracılığıyla tez çalışmasının amaçları ve hipotezleri doğrultusunda çeşitli istatistiksel analizlere tabi tutulmuştur.

Ölçeklerden elde edilen verilere göre gruplar arası farklılıkların incelenmesi için varyansların homojenliğini inceleyen Levene değeri dikkate alınarak iki grup olan yerlerde bağımsız örneklemler t-testi (independent sample t-test), üç ve üçten fazla grup olan yerlerde tek yönlü varyans analizi (One Way ANOVA) kullanılmış, farklılıkların kaynaklarını belirlemek amacıyla tamamlayıcı post-hoc analizleri yapılmıştır. Ayrıca değişkenler arasında ilişki olup olmadığını, ilişki varsa bu ilişkinin şiddetini ve yönünü belirlemek amacıyla korelasyon analizi uygulanmıştır.

\section{BULGULAR}

Tablo 1. Öğretmenlerinin Örgütsel Adalet ve Örgütsel Sessizlik Düzeylerine İlişkin İstatistikler

\begin{tabular}{lllcc}
\hline Ölçek & Alt Boyutlar & $\mathrm{N}$ & SS \\
\hline \multirow{3}{*}{ Örgütsel Adalet } & Dağıtımsal Adalet & 350 & 2.68 & .93 \\
& İşlemsel Adalet & 350 & 3.43 & .99 \\
& Etkileşimsel Adalet & 350 & 3.75 & 1.02 \\
& Toplam & 350 & 3.39 & .88 \\
\hline \multirow{3}{*}{ Örgütsel Sessizlik } & Kabullenici Sessizlik & 350 & 2.26 & .85 \\
& Savunmacı Sessizlik & 350 & 1.77 & .83 \\
& Korumaci Sessizlik & 350 & 4.09 & .91 \\
& Toplam & 350 & 2.71 & .56 \\
\hline
\end{tabular}

Tablo 1'e göre, örgütsel adaletin geneline ilişkin $\operatorname{alg} 1(\bar{x}=3.39) \quad 2.61-3.40$ aralı̆̆ında olup orta düzeyde olmakla beraber yüksek düzeye yakındır. Bu durumda öğretmenlerin örgütsel adalete ilişkin algılarının yüksek düzeyde olduğu söylenebilir. İşlemsel adalet $(\bar{X}=3.43)$ ve 
etkileşimsel adalet $(\bar{X}=3.75)$ alt boyut maddeleri ise yüksek seviyede alg1-lanmakta iken dağ1tımsal adalet alt boyut maddeleri

$(\bar{X}=2.68)$ orta düzeyde algılanmaktadır. Örgütsel sessizliğin geneline ilişkin alg1 $(\bar{X}=2,71)$ ise
2.61-3.40 aralığında olup orta düzeydedir. Kabullenici sessizlik düzey ortalaması $(\bar{X}=2,26)$ düşük düzeyde, savunmacı sessizlik düzey ortalaması $(\bar{X}=1,77)$ çok düşük düzeyde ve korumacı sessizlik düzey ortalaması $(\bar{X}=4,09)$ ise yüksek düzeydedir.

Tablo 2. Öğretmenlerinin Cinsiyetlerine Göre Örgütsel Sessizlik ve Örgütsel Adalet Ölçekleri

Puanlarına İlişkin T-testi Analizi

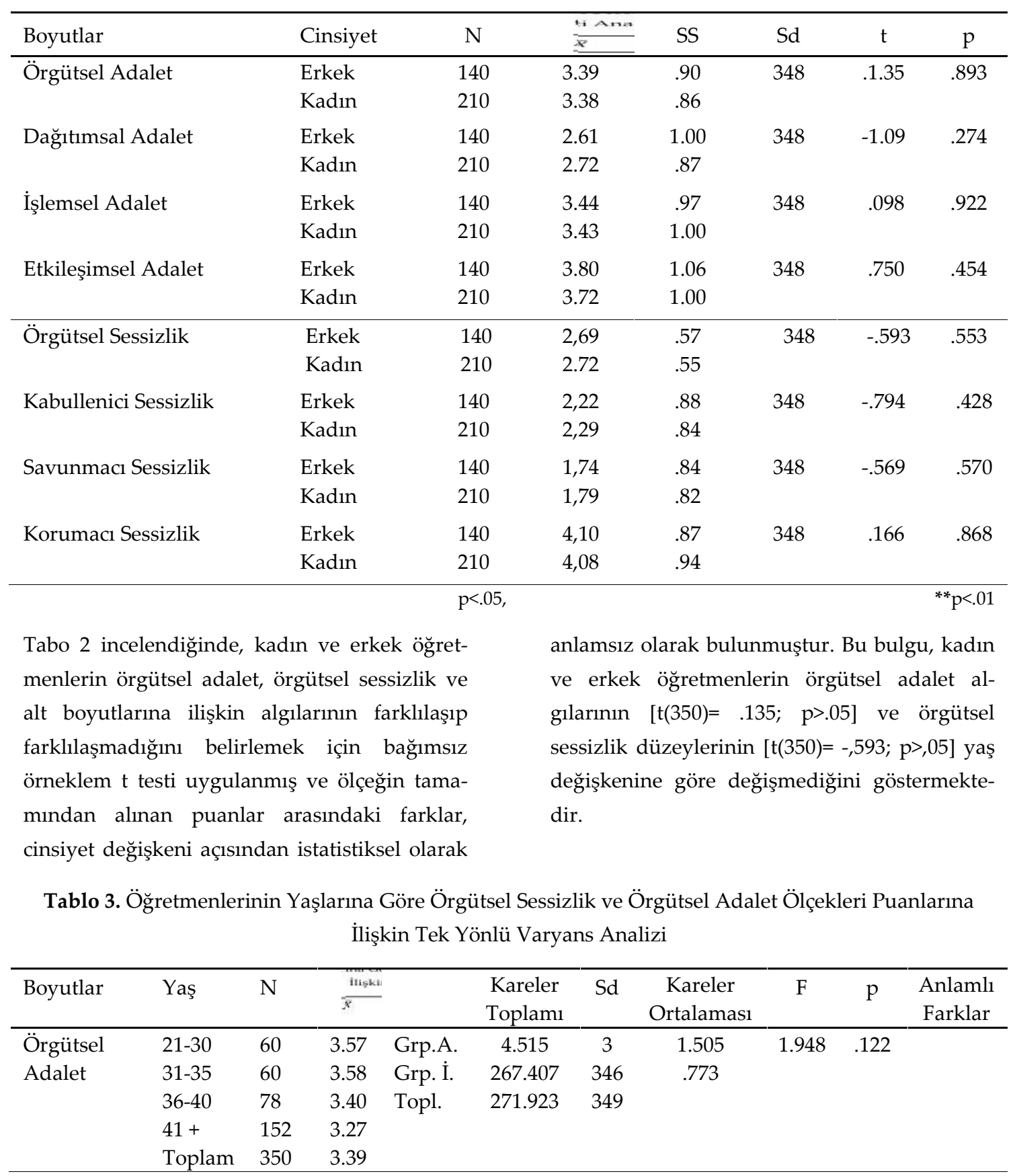




\begin{tabular}{|c|c|c|c|c|c|c|c|c|c|c|}
\hline Dağıtımsal & $21-30$ & 60 & 3.02 & Grp.A. & 9.648 & 3 & 3.216 & 3.807 & $.01^{*}$ & A - D \\
\hline \multirow[t]{4}{*}{ Adalet } & $31-35$ & 60 & 2.69 & Grp. İ. & 292.282 & 346 & .845 & & & \\
\hline & $36-40$ & 78 & 2.67 & Topl. & 301.931 & 349 & & & & \\
\hline & $41+$ & 152 & 2.55 & & & & & & & \\
\hline & Toplam & 350 & 2.68 & & & & & & & \\
\hline İșlemsel & $21-30$ & 60 & 3.54 & Grp.A. & 2.782 & 3 & .927 & .941 & .421 & \\
\hline \multirow{4}{*}{ Adalet } & $31-35$ & 60 & 3.56 & Grp. İ. & 340.784 & 346 & .985 & & & \\
\hline & $36-40$ & 78 & 3.42 & Topl. & 343.566 & 349 & & & & \\
\hline & $41+$ & 152 & 3.34 & & & & & & & \\
\hline & Toplam & 350 & 3.43 & & & & & & & \\
\hline Etkileşimsel & $21-30$ & 60 & 3.89 & Grp.A. & 4.539 & 3 & 1.513 & 1.434 & .233 & \\
\hline \multirow[t]{4}{*}{ Adalet } & $31-35$ & 60 & 3.87 & Grp. İ. & 3365.137 & 346 & 1.055 & & & \\
\hline & $36-40$ & 78 & 3.80 & Topl. & 369.675 & 349 & & & & \\
\hline & $41+$ & 152 & 3.63 & & & & & & & \\
\hline & Toplam & 350 & 3.75 & & & & & & & \\
\hline Örgütsel & $21-30$ & 60 & 2,83 & Grp.A. & 1.617 & 3 & .539 & 1.701 & .167 & \\
\hline \multirow{4}{*}{ Sessizlik } & $31-35$ & 60 & 2,76 & Grp. İ. & 109.657 & 346 & .317 & & & \\
\hline & $36-40$ & 78 & 2,65 & Topl. & 111.274 & 349 & & & & \\
\hline & $41+$ & 152 & 2,66 & & & & & & & \\
\hline & Toplam & 350 & 2,71 & & & & & & & \\
\hline Kabullenici & $21-30$ & 60 & 2,45 & Grp.A. & 3.104 & 3 & 1.035 & 1.404 & .241 & \\
\hline \multirow[t]{4}{*}{ Sessizlik } & $31-35$ & 60 & 2,32 & Grp. İ. & 254.912 & 346 & .737 & & & \\
\hline & $36-40$ & 78 & 2,23 & Topl. & 258.016 & 349 & & & & \\
\hline & $41+$ & 152 & 2,19 & & & & & & & \\
\hline & Toplam & 350 & 2,26 & & & & & & & \\
\hline Savunmacı & $21-30$ & 60 & 1,92 & Grp.A. & 2.783 & 3 & .928 & 1.348 & .259 & \\
\hline \multirow[t]{4}{*}{ Sessizlik } & $31-35$ & 60 & 1,84 & Grp. İ. & 238.233 & 346 & .689 & & & \\
\hline & $36-40$ & 78 & 1,66 & Topl. & 241.016 & 349 & & & & \\
\hline & $41+$ & 152 & 1,73 & & & & & & & \\
\hline & Toplam & 350 & 1,77 & & & & & & & \\
\hline Korumac1 & $21-30$ & 60 & 4,13 & Grp.A. & .286 & 3 & .095 & .113 & .953 & \\
\hline \multirow[t]{4}{*}{ Sessizlik } & $31-35$ & 60 & 4,13 & Grp. İ. & 292.803 & 346 & .846 & & & \\
\hline & $36-40$ & 78 & 4,06 & Topl. & 293.089 & 349 & & & & \\
\hline & $41+$ & 152 & 4,07 & & & & & & & \\
\hline & Toplam & 350 & 4,09 & & & & & & & \\
\hline
\end{tabular}

Tablo 3'de yer alan değerler incelendiğinde, yaş boyutundan elde edilen puanlar arasında anlamlı farklılıkların bulunup bulunmadığ 1 amacıyla yapılan ANOVA testi sonuçlarına göre, örgütsel adalet $[F(3,346)=1.948 ; p>.05]$ ve örgütsel sessizlik $[\mathrm{F}(3,346)=1.701 ; \mathrm{p}>.05]$ boyutlarında ortalamalar arasında $\mathrm{p}<.05$ düzeyinde anlamlı farklılıklar bulun-mamaktadır. Yani farklı yaş gruplarındaki öğret-menlerin örgütsel adalet algıları ve örgütsel sessizlik düzeyleri arasında istatistiksel olarak anlamlı bir fark bulunmamaktadır. Alt boyutlar ince- lendiğinde, dağıtımsal adalet boyutunda yaş grupları açısından istatistiksel olarak anlamlı bir fark bulunmaktadır $[\mathrm{F}(3,346)=3.807 ; \mathrm{p}<.05]$. Yaş değişkenine göre hangi gruplar arasında farkların olduğunu belirlemek amaciyla yapılan Tukey testi sonuçlarına göre, 21-30 yaş grubunda bulunan öğretmenlerin dağıtımsal adalet algıları 41 ve üstü yaş grubu öğretmenlerden anlamlı olarak farklı ve yüksektir. 
Tablo 4. Öğretmenlerinin Görev Yaptıkları Okul Türüne Göre Örgütsel Sessizlik ve Örgütsel Adalet Ölçekleri Puanlarına İlişkin Tek Yönlü Varyans Analizi

\begin{tabular}{|c|c|c|c|c|c|c|c|c|c|c|}
\hline Boyutlar & Okul & $\mathrm{N}$ & $\frac{\text { Glarine }}{\bar{x}}$ & & $\begin{array}{c}\text { Kareler } \\
\text { Top. }\end{array}$ & $\mathrm{Sd}$ & $\begin{array}{c}\text { Kareler } \\
\text { Ort. }\end{array}$ & $\mathrm{F}$ & $\mathrm{p}$ & Farklar \\
\hline Örgütsel & İlkokul & 109 & 3.41 & Grp.A. & 14.499 & 2 & 7.249 & 9.972 & $0.00^{* *}$ & L-İ \\
\hline \multirow[t]{3}{*}{ Adalet } & Ort.Ok. & 112 & 3.64 & Grp. İ. & 257.424 & 347 & .742 & & & $\mathrm{~L}-\mathrm{O}$ \\
\hline & Lise & 129 & 3.15 & Top. & 271.923 & 349 & & & & \\
\hline & Toplam & 350 & 3.39 & & & & & & & \\
\hline Dağıtımsal & İlkokul & 109 & 2.61 & Grp.A. & 11.588 & 2 & 5.794 & 6.925 & $0.01^{*}$ & O-İ \\
\hline \multirow[t]{3}{*}{ Adalet } & Ort.Ok. & 112 & 2.94 & Grp. İ. & 290.343 & 347 & .837 & & & O-L \\
\hline & Lise & 129 & 2.51 & Top. & 301.931 & 349 & & & & \\
\hline & Toplam & 350 & 2.68 & & & & & & & \\
\hline İşlemsel & İlkokul & 109 & 3.46 & Grp.A. & 19.151 & 2 & 9.575 & 9.242 & $0.00^{* *}$ & L-İ \\
\hline \multirow[t]{3}{*}{ Adalet } & Ort.Ok. & 112 & 3.72 & Grp. İ. & 324.415 & 347 & .935 & & & $\mathrm{~L}-\mathrm{O}$ \\
\hline & Lise & 129 & 3.15 & Top. & 343.566 & 349 & & & & \\
\hline & Toplam & 350 & 3.43 & & & & & & & \\
\hline Etkileşimsel & İlkokul & 109 & 3.83 & Grp.A. & 14.65 & 2 & 7.317 & 7.152 & $0.01^{*}$ & L-İ \\
\hline \multirow[t]{3}{*}{ Adalet } & Ort.Ok. & 112 & 3.97 & Grp. İ. & 355.041 & 347 & 1.023 & & & $\mathrm{~L}-\mathrm{O}$ \\
\hline & Lise & 129 & 3.49 & Top. & 369.675 & 349 & & & & \\
\hline & Toplam & 350 & 3.75 & & & & & & & \\
\hline Örgütsel & İlkokul & 109 & 2.63 & Grp.A. & 1.001 & 2 & .501 & 1.575 & 0.208 & \\
\hline \multirow[t]{3}{*}{ Sessizlik } & Ort.Ok. & 112 & 2.77 & Grp. İ. & 110.273 & 347 & .318 & & & \\
\hline & Lise & 129 & 2.71 & Top. & 111.274 & 349 & & & & \\
\hline & Toplam & 350 & 2.71 & & & & & & & \\
\hline Kabullenici & İlkokul & 109 & 2.12 & Grp.A. & 3.499 & 2 & 1.750 & 2.385 & 0.094 & \\
\hline \multirow[t]{3}{*}{ Sessizlik } & Ort.Ok. & 112 & 2.36 & Grp. İ. & 254.517 & 347 & .733 & & & \\
\hline & Lise & 129 & 2.30 & Top. & 258.016 & 349 & & & & \\
\hline & Toplam & 350 & 2.26 & & & & & & & \\
\hline Savunmacı & İlkokul & 109 & 1.55 & Grp.A. & 8.506 & 2 & 4.253 & 6.347 & $0.02^{*}$ & $\dot{\mathrm{I}}-\mathrm{L}$ \\
\hline \multirow[t]{3}{*}{ Sessizlik } & Ort.Ok. & 112 & 1.79 & Grp. İ. & 232.511 & 347 & .670 & & & \\
\hline & Lise & 129 & 1.93 & Top. & 241.016 & 349 & & & & \\
\hline & Toplam & 350 & 1.77 & & & & & & & \\
\hline Korumacı & İlkokul & 109 & 4.23 & Grp.A. & 6.727 & 2 & 3.364 & 4.076 & $0.018^{*}$ & $\dot{\mathrm{I}}-\mathrm{L}$ \\
\hline \multirow[t]{3}{*}{ Sessizlik } & Ort.Ok. & 112 & 4.15 & Grp. İ. & 286.361 & 347 & .825 & & & \\
\hline & Lise & 129 & 3.91 & Top. & 293.089 & 349 & & & & \\
\hline & Toplam & 350 & 4.09 & & & & & & & \\
\hline
\end{tabular}

Tablo 4 incelendiğinde, görev yapılan okul türü boyutunda örgütsel adalet algısına ilişkin istatistiksel olarak anlamlı bir fark olduğu görülmektedir $[F(2,347)=9.972 ; p<.01]$. Görev yapılan okul değişkenine göre hangi gruplar arasında farkların oldugunu belirlemek amaciyla yapılan Tukey testi sonuçlarına göre, liselerde görev yapan öğretmenlerin $(\bar{X}=3.65)$ örgütsel adalet algıları, ilkokullarda $(\bar{X}=3.41)$ ve ortaokullarda $(\bar{X}=3.65)$ görevli öğretmenlerin görüşlerinden farklılık göstermektedir. Liselerde görev yapan öğretmenlerin örgütsel adalet algıları ilkokul ve ortaokul öğretmenlerine göre daha düşüktür.
Dağıtımsal adalet alt boyutu incelendiğinde, görev yapılan okul türü boyutunda dağıtımsal adalet algısına ilişkin istatistiksel olarak anlamlı bir fark olduğu görülmektedir $[\mathrm{F}(2,347)=6.925 ; \mathrm{p}<.05]$, Ortaokullarda görev yapan öğretmenlerin $(\bar{X}=3.94)$ dağ1tımsal adalet algıları, ilkokullarda $(\bar{X}=3.61)$ ve liselerde ( $\bar{X}=3.51)$ görevli öğretmenlerin görüş-lerinden farklılık göstermektedir. Ortaokullarda görev yapan öğretmenlerin dağıtımsal adalet algıları ilkokul ve lise öğretmenlerine göre daha yüksektir. İşlemsel ve etkileşimsel adalet alt boyutları incelen-diğinde, görev yapılan okul türü boyutunda işlemsel $[F(2,347)=10.242 ; p<.01]$ ve etkileşimsel $[F(2,347)=$ 7.152; $\mathrm{p}<.05]$ adalet algılarına ilişkin istatistiksel olarak anlamlı bir farklar olduğu görülmektedir. 
Tukey testi sonuçlarına göre, liselerde görev yapan öğretmenlerin işlemsel $(\bar{X}(\mathrm{i})=3.15)$ ve etkileşimsel $(\bar{X}$ (e)=3.49) adalet algıları, ilkokullarda $(\bar{X}(\mathrm{i})=3.46, \bar{X}$ $(\mathrm{e})=3.83)$ ve ortaokullarda $(\bar{X} \quad(\mathrm{i})=3.72, \quad X(\mathrm{e})=3.97)$ görev yapan öğretmenlere göre daha düşüktür.

Örgütsel sessizlik boyutunda ortalamalar arasında anlamlı farklılıklar bulunma-maktadır $[F(2,347)=$
1.575; p>.05]. Örgütsel sessizlik alt boyutlan incelendiğinde, ilkokul öğretmenlerinin $(\bar{X}=1.55)$ savunmacı sessizlik düzeyleri lise öğretmenlerinin $(\bar{X}=$ 1.93) savunmacı sessizlik düzeylerinden daha düşüktür. Korumacı sessizlik alt boyutu açısından, ilkokul öğretmenlerinin $(\bar{X}=4.23)$ sessizlik düzeyleri lise öğretmenlerinden $(\bar{X}=3.91)$ daha yüksektir.

Tablo 5. Öğretmenlerinin Çalıştıkları Kurumlardaki Algıladıkları Yönetim Tarzına Göre Örgütsel Sessizlik ve Örgütsel Adalet Ölçekleri Puanlarına İlişkin Tek Yönlü Varyans Analizi

\begin{tabular}{|c|c|c|c|c|c|c|c|c|c|c|}
\hline Boyutlar & Alg1 & $\mathrm{N}$ & Ölçek & & $\begin{array}{c}\text { Kareler } \\
\text { Top. }\end{array}$ & Sd & $\begin{array}{c}\text { Kareler } \\
\text { Ort. }\end{array}$ & $\mathrm{F}$ & $\mathrm{p}$ & Farkl \\
\hline Örgütsel & Dem. & 212 & 3,75 & Grp.A. & 91,793 & 2 & 45,897 & 88,295 &, $000^{* *}$ & $\mathrm{D}-\mathrm{O}$ \\
\hline \multirow[t]{3}{*}{ Adalet } & Otok. & 88 & 2,54 & Grp. İ. & 179,334 & 345 & ,520 & & & D-S \\
\hline & Ser.B & 48 & 3,31 & Top. & 271,127 & 347 & & & & O-S \\
\hline & Top. & 348 & 3,39 & & & & & & & \\
\hline Dağıtımsal & Dem. & 212 & 2,92 & Grp.A. & 40,101 & 2 & 20,051 & 26,513 &, $000^{* *}$ & $\mathrm{D}-\mathrm{O}$ \\
\hline \multirow[t]{3}{*}{ Adalet } & Otok. & 88 & 2,12 & Grp. İ. & 260,909 & 345 & ,756 & & & D-S \\
\hline & Ser.B & 48 & 2,63 & Top. & 301,010 & 347 & & & & O-S \\
\hline & Top. & 348 & 2,68 & & & & & & & \\
\hline İşlemsel & Dem. & 212 & 3,86 & Grp.A. & 119,156 & 2 & 59,578 & 91,645 &, $000^{* *}$ & $\mathrm{D}-\mathrm{O}$ \\
\hline \multirow[t]{3}{*}{ Adalet } & Otok. & 88 & 2,49 & Grp. İ. & 224,284 & 345 & 650 & & & D-S \\
\hline & Ser.B & 48 & 3,25 & Top. & 343,440 & 347 & & & & O-S \\
\hline & Top. & 348 & 3,43 & & & & & & & \\
\hline \multirow{4}{*}{$\begin{array}{l}\text { Etkileşimsel } \\
\text { Adalet }\end{array}$} & Dem. & 212 & 4,15 & Grp.A. & 110,414 & 2 & 55,207 & 73,915 &, $000^{* *}$ & $\mathrm{D}-\mathrm{O}$ \\
\hline & Otok. & 88 & 2,81 & Grp. İ. & 257,680 & 345 & 747 & & & D-S \\
\hline & Ser.B & 48 & 3,72 & Top. & 368,094 & 347 & & & & O-S \\
\hline & Top. & 348 & 3,75 & & & & & & & \\
\hline Örgütsel & Dem. & 212 & 2.68 & Grp.A. & .231 & 2 & .115 & .361 & .697 & \\
\hline \multirow[t]{3}{*}{ Sessizlik } & Otok. & 88 & 2.74 & Grp. İ. & 110.045 & 345 & .319 & & & \\
\hline & Ser.B & 48 & 2.63 & Top. & 110.275 & 347 & & & & \\
\hline & Top. & 348 & 2.70 & & & & & & & \\
\hline Kabullenici & Dem. & 212 & 2.29 & Grp.A. & .479 & 2 & .240 & .323 & .724 & \\
\hline \multirow[t]{3}{*}{ Sessizlik } & Otok. & 88 & 2.23 & Grp. İ. & 255.968 & 345 & .742 & & & \\
\hline & Ser.B & 48 & 2.20 & Top. & 256.447 & 347 & & & & \\
\hline & Top. & 348 & 2.26 & & & & & & & \\
\hline Savunmacı & Dem. & 212 & 1.63 & Grp.A. & 9.093 & 2 & 4.547 & 6.839 & $.001^{* *}$ & $\mathrm{D}-\mathrm{O}$ \\
\hline \multirow[t]{3}{*}{ Sessizlik } & Otok. & 88 & 1.95 & Grp. İ. & 229.346 & 345 & .665 & & & D-S \\
\hline & Ser.B & 48 & 1.99 & Top. & 238.439 & 347 & & & & \\
\hline & Top. & 348 & 1.76 & & & & & & & \\
\hline Korumacı & Dem. & 212 & 4.13 & Grp.A. & .990 & 2 & .495 & .587 & .556 & \\
\hline \multirow[t]{3}{*}{ Sessizlik } & Otok. & 88 & 4.05 & Grp. İ. & 290.801 & 345 & .843 & & & \\
\hline & Ser.B & 48 & 3,98 & Top. & 291.791 & 347 & & & & \\
\hline & Top. & 348 & 4,09 & & & & & & & \\
\hline
\end{tabular}


Tablo 5‘de yer alan değerler incelendiğinde, çalışılan kurumda algılanan yönetim tarzı değişkeninden elde edilen puanlar arasında anlamlı farklılıkların bulunup bulunmadığı amacıyla yapılan ANOVA testi sonuçlarına göre, örgütsel adalet boyutunda ortalamalar arasında istatistiksel olarak anlamlı farklılıklar bulunmaktadır. $[\mathrm{F}(2,345)=88.295 ; \mathrm{p}<.01]$.

Örgütsel adaletin alt boyutları açısından farkın kaynağını bulmak için yapılan Post-Hoc testlerinde tüm boyutlar için aynı sonuç elde edilmiş, farkların tüm değişkenlerin ikili olarak farklarından kaynaklandı̆̆ 1 ve istatistiksel olarak $\mathrm{p}<.01$ düzeyinde anlamlı olduğu analiz edilmiştir. Tüm alt boyutlar için, çalıştıkları okullardaki yönetim tarzının demokratik olduğunu düşünen öğretmenlerin algıları $(\bar{X}$ $($ ÖA $)=3.75, \quad \bar{X} \quad(\mathrm{DA})=2.92, \quad \bar{X} \quad($ İA $)=3.86, \quad \bar{X}$
$(\mathrm{EA})=4.15)$, serbest birakıcı $(\bar{X} \quad($ ÖA $)=3.31, \bar{X}$ $(\mathrm{DA})=2.63, \bar{X}(\dot{\mathrm{I} A})=3.25,(\mathrm{EA})=3.72)$ ve otokratik $(\bar{X} \quad(\mathrm{ÖA})=2.54, \bar{X} \quad(\mathrm{DA})=2.12, \bar{X} \quad($ İA $)=2.49, \bar{X}$ $(\mathrm{E} A)=2.81$ ) olduğunu düşünenlerden yüksek çıkmıştır. Örgütsel sessizlik boyutunda ortalamalar arasında istatistiksel olarak anlamlı bir fark bulunmamaktadır $[\mathrm{F}(2,345)=.361 ; \mathrm{p}>.05]$. Örgütsel sessizlik alt boyutlarından sadece savunmacı sessizlik $[\mathrm{F}(2,345)=6.839 ; \mathrm{p}<.01]$ alt boyutunda istatistiksel olarak anlamlı bir fark bulunmaktadır. Tukey testi sonuçlarına göre, çalıştıkları kuruma algıladıkları yönetim tarzı demokratik olanların $(x=1.63)$ algıları otokratik $(\bar{X}=1.95)$ ve alg1sı serbest birakıcı $(\bar{X}=1.99)$ olanlara göre istatistiksel olarak anlamlı şekilde farklıdır. Yani kurumlarına karşı algıları demokratik olanların savunmacı sessizlik düzeyleri diğerlerine göre daha düşüktür.

Tablo 6. Örgütsel Adalet ve Örgüt Sessizlik Ölçeklerinin Alt Boyutlarına İlişkin Korelasyon Tablosu

\begin{tabular}{|c|c|c|c|c|c|c|c|c|}
\hline & $\begin{array}{c}\text { Örgütsel } \\
\text { Adalet }\end{array}$ & $\begin{array}{l}\text { Dağıt. } \\
\text { Adalet }\end{array}$ & $\begin{array}{l}\text { İşlem. } \\
\text { Adalet }\end{array}$ & $\begin{array}{l}\text { Etkileş. } \\
\text { Adalet }\end{array}$ & $\begin{array}{l}\text { Örgütsel } \\
\text { Sessizlik }\end{array}$ & $\begin{array}{c}\text { Kabul. } \\
\text { Sessizlik }\end{array}$ & $\begin{array}{l}\text { Savun. } \\
\text { Sessizlik }\end{array}$ & $\begin{array}{c}\text { Koru. } \\
\text { Sessizlik }\end{array}$ \\
\hline $\begin{array}{l}\text { Örgütsel } \\
\text { Adalet }\end{array}$ & 1 & & & & & & & \\
\hline $\begin{array}{l}\text { Dağıtımsal } \\
\text { Adalet }\end{array}$ & $\begin{array}{l}.712^{* *} \\
.000\end{array}$ & 1 & & & & & & \\
\hline $\begin{array}{l}\text { İşlemsel } \\
\text { Adalet }\end{array}$ & $\begin{array}{l}.939^{* *} \\
.000\end{array}$ & $\begin{array}{l}.567^{* *} \\
.000\end{array}$ & 1 & & & & & \\
\hline $\begin{array}{l}\text { Etkileşimsel } \\
\text { Adalet }\end{array}$ & $\begin{array}{l}.945^{* *} \\
.000\end{array}$ & $\begin{array}{l}.491^{* *} \\
.000\end{array}$ & $\begin{array}{l}.863^{* *} \\
.000\end{array}$ & 1 & & & & \\
\hline $\begin{array}{l}\text { Örgütsel } \\
\text { Sessizlik }\end{array}$ & $\begin{array}{l}-.012 \\
.822\end{array}$ & $\begin{array}{l}.136^{*} \\
.011\end{array}$ & $\begin{array}{l}-.012 \\
.822\end{array}$ & $\begin{array}{l}-.039 \\
.465\end{array}$ & 1 & & & \\
\hline $\begin{array}{l}\text { Kabullenici } \\
\text { Sessizlik }\end{array}$ & $\begin{array}{l}.092 \\
.087\end{array}$ & $\begin{array}{l}.252^{* *} \\
.000\end{array}$ & $\begin{array}{l}.065 \\
.228\end{array}$ & $\begin{array}{l}.005 \\
.926\end{array}$ & $\begin{array}{l}.761^{* *} \\
.000\end{array}$ & 1 & & \\
\hline $\begin{array}{l}\text { Savunmacı } \\
\text { Sessizlik }\end{array}$ & $\begin{array}{l}-.205^{* *} \\
.000\end{array}$ & $\begin{array}{l}-.022 \\
.685\end{array}$ & $\begin{array}{l}-.207^{* *} \\
.000\end{array}$ & $\begin{array}{l}-.248^{* *} \\
.000\end{array}$ & $\begin{array}{l}.743^{* *} \\
.000\end{array}$ & $\begin{array}{l}.596^{* *} \\
.000\end{array}$ & 1 & \\
\hline $\begin{array}{l}\text { Korumacı } \\
\text { Sessizlik }\end{array}$ & $\begin{array}{l}.123^{*} \\
.021\end{array}$ & $\begin{array}{l}.036 \\
.501\end{array}$ & $\begin{array}{l}.106^{*} \\
.049\end{array}$ & $\begin{array}{l}.149^{* *} \\
.005\end{array}$ & $\begin{array}{l}.460^{* *} \\
.000\end{array}$ & $\begin{array}{l}-.071 \\
.185\end{array}$ & $\begin{array}{l}-092 \\
.085\end{array}$ & 1 \\
\hline
\end{tabular}

${ }^{*} \mathrm{p}<.05,{ }^{* *} \mathrm{p}<.01$

Tablo 6'ya göre, katılımcıların örgütsel adalet ve örgütsel sessizlik ölçeklerinden aldıkları puanlar kıyaslandığında düşük düzeyde nega- tif ve istatistiksel olarak anlamsız bir ilişki (r=.012; p>.05) olduğu görülmektedir. 
Örgütsel adalet ölçeği ve örgütsel sessizlik ölçeğinin alt boyutları kıyaslandığında; örgütsel adalet ile kabullenici sessizlik ( $r=.092$; $p>, 05)$ arasında düşük düzeyde pozitif ve istatistiksel olarak anlamsız bir ilişki, örgütsel adalet ile savunmacı sessizlik $(r=-, 205 ; \mathrm{p}<, 01)$ arasında düşük düzeyde negatif ve istatistiksel olarak anlamlı bir ilişki ve örgütsel adalet ile korumacı sessizlik arasında $(\mathrm{r}=.123 ; \mathrm{p}<.05)$ düşük düzeyde pozitif ve istatistiksel olarak anlamlı bir ilişki olduğu görülmektedir. Örgütsel sessizlik ölçeği ve örgütsel adalet ölçeğinin alt boyutları kıyaslandığında; örgütsel sessizlik ile dağıtımsal adalet $(r=.136 ; \quad p<.05)$ arasinda düşük düzeyde pozitif ve istatistiksel olarak anlamlı bir ilişki, örgütsel sessizlik ile işlemsel adalet ( $r=-.012 ; \mathrm{p}>.05)$ arasında düşük düzeyde negatif ve istatistik-sel olarak anlamsız bir ilişki ve örgütsel sessizlik ile etkileşimsel adalet arasında ( $r=-.039 ; \mathrm{p}>.05)$ düşük düzeyde negatif ve istatistiksel olarak anlamsız bir ilişki olduğu görülmektedir.

Katılımclar tarafından cevaplanan her iki ölçekten alınan puanlar alt boyutlar bazında karşılaştırıl-dığında ise korelasyon verilerine göre kabullenici sessizlik alt boyutu ile dağ ${ }^{-}$ tımsal adalet alt boyutu ( $r=-.252 ; \mathrm{p}<.01)$ arasında düşük düzeyde pozitif ve istatistiksel olarak anlamlı bir ilişki, savunmacı sessizlik ile işlemsel ve etkileşimsel adalet alt boyutları arasinda (sirasiyla $\mathrm{r}=-.207, \mathrm{p}<, 01 ; \mathrm{r}=-.248, \mathrm{p}<$ .01 ), korumacı sessizlik ile etkileşimsel adalet arasında $(\mathrm{r}=.149 ; \mathrm{p}<.01)$ düşük düzeyde pozitif ve istatistiksel olarak anlamlı bir ilişki olduğu görülmektedir.

\section{TARTIŞMA ve SONUÇ}

Araştırma sonucunda kadın ve erkek öğretmenlerin örgütsel adalet algılarının ve sessizlik düzeylerinin cinsiyet değişkeni açısından anlamlı olarak farklılaşmadığı sonucuna ulaşılmıştır. Alan yazın incelendiğinde; Doğan (2008), Karaman (2009), Ertürk (2011) ve Çelik
(2011) öğretmenlerinin örgütsel adalet ve alt boyutlarına ilişkin algılarının cinsiyet değişkeni açısından farklılık göstermediğini, Kahveci (2010) ve Yanık (2012) öğretmenlerin sessizlik davranışlarına yönelik araştırmalarında cinsiyet değişkeninin öğretmenlerin sessizlik düzeylerinde anlamlı bir farklılık yaratmadığını analiz etmişlerdir. Bu sonuçlar araştırma ile paralellik göstermektedir. Polat (2007) erkek öğretmenlerin genel, dağıtımsal ve etkileşimsel adalet algılarının kadın öğretmenlere göre daha yüksek olduğunu tespit etmiş, bu etkinin okul yöneticilerinin çoğunluğunun erkek olmasına, bu yöneticilerin erkek öğretmenlerle daha kolay iletişim ve etkileşime girmelerine; buna bağlı olarak, erkek öğretmenlerin okul yöneticilerinin davranış ve uygulamalarını daha adil algılamalarına dayandırmıştır. Polat (2007)'ın araştırmasında yer alan öğretmenlerin \%45.5'i mesleki ve teknik liselerde görev yapması nedeniyle böyle bir sonuca ulaştığı söylenebilir. Genel anlamda alan yazındaki araştırmalarda değerlendirildiğinde cinsiyetin adalet algısı ve sessizlik davranışında bir etmen olmadığı söylenebilir.

Yaş grubu açısından incelendiğinde, tüm adalet ve sessizlik boyutlarında yaş grubu arttıkça ortalamalar bazında adalet algısının düştügü ve sessizlik davranışının azaldığı, sadece dağ ${ }^{-}$ tımsal adalet boyutunda farklılığın istatistiksel olarak anlamlı olduğu analiz edilmiştir. Yaş arttıkça dağıtımsal adalet algısı azalmaktadır. Bu farklılık, mesleğe yeni başlayan öğretmenin, günümüz şartlarında elde ettiği başarı ve arzu ile dağıtılan iş yükü, ödül, çalışma programı gibi hususları yüksek alg1 derecesi ile algılamasından ve yaş grubunun ilerlemesi ile beklentilerin farklılaşması neticesinde dağıtımsal adalet algılarının azalmasından kaynaklanmış olabilir. Yürür (2008) ve İmamoğlu (2011) örgütsel adalet algısının ve alt boyutlarının yaş değişkenine göre farklılaşmadığını saptamışlardır. Ertürk (2011) araştırmasında tüm boyutlarda adalete 
ilişkin öğretmen algılarının yaş ilerledikçe azaldığını değerlendirmiştir. Bu sonuçlar araştırma ile kısmen uyum göstermektedir.

Araştırmada görev yapılan okul bağlamında örgütsel adaletin geneli, işlemsel ve etkileşimsel adalet boyutlarında lise öğretmenlerinin ilkokul ve ortaokul öğretmenlerine göre anlam1 şekilde daha düşük bir adalet algısına sahip olduğu, dağıtımsal adalet boyutunda ortaokul öğretmenlerinin ilkokul ve lise öğretmenlerine göre daha yüksek algıya sahip olduğu tespit edilmiştir.

Örgütsel sessizlik boyutlarından sadece savunmacı ve korumacı sessizlik boyutlarında anlamlı fark meydana gelmiştir. Savunmacı sessizlik boyutunda lise öğretmenlerinin sessizlik düzeyi en yüksekken, ilköğretim öğretmenlerinin en düşük çıkmıştır. Korumacı sessizlik boyutunda ise lise öğretmenleri en düşük düzeyde iken ilkokul öğretmenleri en yüksek düzeyde çıkmıştır.

Örgütsel sessizliğin geneli ve kabullenici sessizlik boyutlarında ortaokul öğretmenlerinin en yüksek düzeye sahip olduğu görülmektedir. Ortaokul öğretmenlerinin tüm boyutlarda adalet algıları diğerlerine göre yüksek iken, genel sessizlik ve kabullenici sessizlik düzeyleri en yüksektir. Olağandan farklı gelişen bu durum fayda maliyet kuramı bağlamında gerçekleşmiş olabilir. Yöneticiler gibi, çalışanlar da fayda-maliyet çözüm-lemesi çerçevesinde düşünürler. Çalışanlar hoşnut olmadıkları bazı durumlarla karşılaştıklarında, diğer bir deyişle, örgüt içerisinde yolunda gitmeyen bir şeyler olduğunda konuşma ya da sessiz kalma kararı verirlerken kayıp kazanç hesabı yaparlar. Konuşarak kazanacakları, konuşmadıklarında kaybedecek-lerinden daha fazla ise kendilerini ifade etme yolunu tercih ederler. Konuşmak daha maliyetli ise sessiz kalmayı tercih ederler. Sessiz kalma ya da konuşma arasında karar verirken göz önünde bulundurulan başlıca etmenler; enerji ve zaman kaybı, dile getirme nedeniyle misillemeyle karşılaşma ya da saygınlık azalması, işte ilerleyeme ya da işten çıkarılma gibi durumlardır (Çakıcı, 2007:152; Premaux ve Bedeian, 2003).

Araştırmada katılımcılara çalıştıkları okullardaki yönetim tarzını nasıl algıladıkları sorulmuş, netice-sinde elde edilen verilerden örgütsel adalet ve alt boyutları ile anlamlı farklar tespit edilmiştir. Okullarındaki yönetim tarzını demokratik olarak algılayan öğretmenlerin adalet ve alt boyutuna ilişkin algıları, serbest bırakıcı ve otokratik diyenlere göre daha yüksek seviyede çıkmıştır. Bu demokrasi ile adalet arasındaki pozitif ilişkinin doğal sonucu olarak değerlendirilmiştir. Buna paralel olarak yönetim tarzını otokratik algılayan öğretmenlerin adalet ve alt boyutlarına ilişkin algı düzeyleri daha düşük olarak tespit edilmiştir. Aynı okullarda örgüt-sel adalet ve alt boyutlarına ilişkin algıların farklılaş-masının nedeni yönetimsel sorunlardan kaynaklı olabilir.

Örgütsel sessizlik ve alt boyutları arasından sadece savunmacı sessizlik boyutunda anlamlı fark tespit edilmiştir. Kurumlarındaki yönetim tarzını demokratik olarak nitelendiren öğretmenlerin savunmacı sessiz kalma davranışları, otokratik ve serbest bırakıcı olarak nitelendirenlere göre anlamlı şekilde düşük çıkmıştır. Okuldaki demokratik ortam, doğası gereği öğretmenlere konuşma, problemleri ve talepleri iletme hakkı vermekte ve bu demokrasi ortamını yaşayabilen öğretmenlerin sessiz kalma davranışı düşük olmakta, yani özgürce savundukları düşünce ve doğruları yöneticilerine iletebil-mektedirler. Savunmacı sessizlik davranışının özellikle yönetici tepkilerine karşı geliştirilen bir davranış olması sebebiyle, demokratik olmayan yönetim tarzlarında öğretmenlerin savunmacı sessizlik düzeylerinin arttığ1 söylenebilir. Yöneticiler, özellikle sessiz kalmanın en önemli sebeplerinden biri olan ve 
çalışanın kendini koru-maya yönelik sessiz kalmasını sağlayacak şekilde korku kültürünü besleyen 'psikoşiddetten' kaçınmalıdır (Yaman ve Ruçlar, 2014). Nitekim, Yaman (2007, 2008, 2009, 2010) ve Yaman, Vidinlioğlu, ve Çitemel (2010) çalışmalarında, psikoşiddete (mobbing) maruz kalmanın örgütsel davranışı, derslerin verimini, akademik çalışmaları, akademik kariyeri, örgütsel sosyalleşmeyi, işyerinde huzuru, aile içi iletişimi, insan psikolojisini, özgüveni ve benliği zedelediğini ve ket vurduğunu bulgulamıştır.

Araştırmada ilköğretim ve ortaöğretim öğretmen-lerinin örgütsel adalet algıları ve örgütsel sessizlik düzeyleri arasında düşük düzeyde, negatif yönlü ve istatistiksel olarak anlamsız bir ilişki olduğu saptan-mıştır. Bu bağlamda ilişkilerin alt boyutlar açısından değerlendirilmesinin daha sağlıklı olacağı değerlen-dirilmiştir.

Alt boyutlar açısından incelendiğinde, kabullenici sessizlik ile örgütsel adaletin geneli ve alt boyutları ile pozitif yönde ve düşük düzeyde bir ilişkiye rastlanılmış olup, bunlardan sadece dağıtımsal adalet boyutunda istatistiksel olarak anlamlı bir ilişki tespit edilmiştir. Bu sonucun, dağıtım adaletine ilişkin hususlardan ödül, iş yükü, çalışma programı, sorumlulukların dağıtılması gibi unsurların yöneticiler tarafından paylaştırılmasında öğretmen-lerin adalet algıları arttıkça kabul edici sessizlik düzeyleri de artarak, unsurları olan değişimlere, alınacak kararlara, problemlere yönelik görüş, düşünce ve fikirlerin açıklanmasında kendilerini sınırlayacakları anlamina gelmektedir. Bu durum fayda maliyet kuramı bağlamında gerçekleşmiş olabilir. Aküzüm (2014) ilköğretim okulu öğretmen-lerinin örgütsel adalet algıları ve sessizlik düzeyleri üzerine yaptığı araştırmada, kabul edici sessizlik ve dağıtımsal adalet arasında istatistiksel olarak anlamlı, negatif ve yüksek düzeyde bir ilişki tespit etmiştir. Bu sonuç araştırma ile uyum göster-memektedir.
Savunmacı sessizlik açısından analiz edildiğinde; örgütsel adaletin geneli, alt boyutlarından işlemsel ve etkileşimsel adalet ile düşük düzeyde, negatif ve istatistiksel olarak anlamlı bir ilişki, dağıtımsal adalet ile negatif yönlü düşük düzeyde anlamsız bir ilişki tespit edilmiştir. Bu sonuç, Aküzüm (2014)'ün araştırması ile dağ1tımsal adalet bağlantısı dışında benzerlik göstermektedir. İşlemsel ve etkileşimsel adalet algılarının artması savunmacı sessizlik düzeyinde önemli ölçüde azalma meydana getirmektedir. Sessizlik düzeyinin düşmesi, sessiz kalma davranışının azalması anlamına gelmektedir. Yani, işle ilgili kararların öğretmene açıklanması, haklarının korunması, bilgi sağlanması, bu işlemler esnasında ve sonrasında davranış tarzı olarak nezaket ve samimiyete önem verilmesi yöneticiden ve tepkisinden korkma hissini azaltacak ve öğretmene işle ilgili bilgileri paylaşmaya, olumsuz durumları göz ardı etmemeye, eksiklikleri ve olumsuzlukları düzeltmeye yönelik fikirleri saklamadan açıklamaya yöneltecektir.

Korumacı sessizlik açısından analiz edildiğinde; örgütsel adaletin geneli, alt boyutlarından işlemsel ve etkileşimsel adalet ile yüksek düzeyde, pozitif ve istatistiksel olarak anlamlı bir ilişki, dağıtımsal adalet ile pozitif yönlü düşük düzeyde anlamsız bir ilişki tespit edilmiştir. Bu sonuç, Aküzüm (2014)'ün araştırmasında etkileşimsel adalet ve korumacı sessizlik ilişkisinde uyum göstermiş, işlemsel ve dağıtımsal adalet ile korumacı sessizlik ilişkisi bağlamında uyum göstermemiştir. Araştırmada öğretmenlerin dağıtımsal adalet algısı düşük olmasına rağmen korumacı sessizlik davranışı yüksek düzeyde gerçekleşmiştir. Bu sonuç, dağıtım-sal unsurların paylaştırılmasında öğretmenlere nezaket ve samimiyet ile yaklaşıldı̆̆ı, görüşleri ve çekincelerinin dinlendiği, alınan kararların neden-lerinin açıklanması durumunda iş arkadaşları ve okulunu koruma güdüleri ile buna ilişkin hususlarda yüksek düzeyde sessiz ka- 
lındığı anlamına gelebilir. Ayrıca dağıtımsal adalet hususları sadece okul yöneticisi ile bağdaştırılmayıp, genel eğitim sistemine de yordanma neticesinde okul ve iş arkadaşlarını yüksek bir koruma sessizliği davranışı geliştirilmiş olabilir.

Sonuç olarak, okul yöneticilerinin yetkilerini (ödül, görev, sorumluluklar vb.) hakkaniyet ile, eşit ve adil olarak kullanmaları, bu işlemler esnasında öğret-menlerin çekincelerinin ve fikirlerinin dinlenmesi, önem verilmesi, gerekli bilgilerin paylaşılması, tarafsız olunması, yine bu işlemler esnasında nezaket, saygınlık, samimiyet ve açıklıkla yaklaşıl-ması, onları güvende hissettirecek, kuruma ve sisteme aidiyet duygularını arttıracaktır. Bu yaklaşım öğretmenlerin problemlere, gelişimi engelleyen hususlara duyarsız ve sessiz kalmasını engelleyecek, bilgi paylaşımı ve açıklık eğitim sisteminin en önemli ilişkilerini oluşturan öğretmen, okul ve yönetici bağlamında ilişkileri dolayısı ile eğitimde verimliliği ve sürekli gelişimi arttıracaktir.

\section{Kaynakça}

Aküzüm, C. (2014). The effect of perceived organizational justice on teachers' silence: A Practice in Primary Education Institutions. International J. Soc. Sci. E Education, 5(1), 96-107.

Alexander, S. ve Ruderman, M, (1987). The role of procedural and distributive justice in organizational behaviour, Social Justice Research, 1, 177-198.

Bendersky, C. (2005). Organizational influence on disputants. The handbook of dispute resolution. Moffitt M. L. ve Bordane R. C., (Ed.). USA: Jossey-Bass Publ.

Bies, R. J., Moag, J. S. (1986). Interactional justice, communication criteria for fairness. In, M. H. Bazerman, R. Sheppard, and B. Sheppard (Eds.). Research in negotiations in organizations. 1, 43-55.

Bies, R. J., Shapiro, D. L. (1987). Interactional fairness judgments, The influence of causal accounts. Social Justice Research, 1:199-218.

Bos, K. V. (2001). Fundamental research by means of labaratory experiments is essential for a better understanding of organizational justice. J. Vocational Behaviour. 58, 254-259

Brinsfield, C., T. (2009). Employee Silence: Investigation of dimensionality, development of measures, and examination of related factors. Dissertation, Ohio State University, USA.

Brinsfield, C. T., Edwards, M. E., ve Greenberg, J. (2009). Voice and silence in organizations: Historical review and current conceptualizations. UK: Emerald Group Publishing Limited.

Brockner, J., Siegel, P., (1996), Understanding the interaction between procedural and distributive justice: The role of trust, trust in organizations: Frontiers of theory and research,. London: Sage Publications.

Çakıcı, A., (2007). Örgütlerde sessizlik: Sessizliğin teorik temelleri ve dinamikleri, Ç.Ü. Sosyal Bilimler Enstitisü Dergisi, 16 (1), 145-162.

Çelik, O. T. 82011). Illköğretim Okulu Yöneticilerinin ve Öğretmenlerinin Örgütsel Adalet Algıları ile İs Doyumları Arasındaki İlişki. Yayımlanmamış Yüksek Lisans Tezi. Selçuk Üniversitesi. 
Dabbagh, P., Esfahani, A.N., ve Shahin, A. (2012). Studying relationship between perceived organizational justice and organizational salience, Institute of Interdisciplinary Business Research, 3(10), 468478 .

Doğan, A. (2008). İlköğretim Kurumlarında Örgütsel Adaletin Örgütsel Bağlılı Üzerine Etkisi (Elazı̆̆ İli Örne$\breve{g}$ i). Yayımlanmamış Yüksek Lisans Tezi. Fırat Üniversitesi.

Dyne, L. V., Ang, S. ve Botero, I. C. (2003). Conceptualizing Employee Silence and Employee Voice as Multidimensional Constructs. Journal of Management Studies, 40 (6), 1359-1392.

Durak, İ. (2012). Korku kültürü ve örgütsel sessizlik. Bursa: Ekin.

Erdogan, B., Kraimer, M. L., ve Liden, R. C. (2001). Procedural justice as a twodimensional construct: an examination in the performance appraisal context. Journal of Applied Behavioral Science, 37, 205222.

Ertürk, E. (2011). Illköğretim ve Ortä̈̆gretim Okullarındaki Örgütsel Adalet Algısı ile Öğretmenlerin Örgütsel Adanmışlıkları Arasındaki İlişki. Yayımlanmamış Yüksek Lisans Lezi. Mehmet Akif Ersoy Üniversitesi.

Folger, R. G., ve Cropanzano, R. (1998). Organizational justice and human resource management (Vol. 7). London: Sage Publications.

Greenberg, J. (1987), A Taxonomy of organizational justice theories, Academy of Management Review, 12, 9-22.

Greenberg, J. (1990a), Looking fair versus being fair: Managing impressions of organizational justice, Research in Organizational Behavior, 12 (1) 11-157.

Greenberg, J. (1990b), Organizational justice: Yesterday, today, tomorrow. Journal of Management, 16:399432.

Gürpınar, G. (2006). An Empirical Study of Relationships Among Organizational Justice, Organizational Commitment, Leader-Member Exchange, and Turnover Intention. Yayımlanmamış Yüksek Lisans Tezi. Yeditepe Üniversitesi, Sosyal Bilimler Enstitüsü, İstanbul.

Hirschman, A. O. (1970). Exit, voice, and loyalty: Responses to decline in firms, organizations, and states. Harvard University Press,25.

İmamoğlu, G. (2011). Illköğretim Okulu Öğretmenlerinin Örgütsel Bă̆lılık Düzeyleri ve Örgütsel Adalet Algıları Arasındaki İlişki. Yayımlanmamış Yüksek Lisans Tezi. Gazi Üniversitesi Eğitim Bilimleri Enstitüsü.

Johannesen, R. L. (1974). The functions of silence: A plea for communication research. Western Journal of Communication (includes Communication Reports), 38(1), 25-35.

Kahveci, G. (2010). İlköğretim Okullarında Örgütsel Sessizlik ile Örgütsel Bă̆lılık Arasındaki İlişki. Yayımlanmamış Yüksek Lisans Tezi. Fırat Üniversitesi Sosyal Bilimler Enstitüsü.

Karacaoğlu, K. ve Cingöz, A. (2008). Örgütsel sessizlik. Özdevecioğlu, M. ve Karadal, H. (Ed.). Örgütsel davranışta seçme konular: Organizasyonların karanlık yönleri ve verimlilik azaltıcı davranışlar içinde. Ankara: İlke Yayınevi. 155-167. 
Karaman, P. (2009). Örgütsel Adalet Algısı ile Tükenmişlik Arasındaki İlişkinin İncelenmesine Yönelik Ö̆ğretmenler Üzerinde Bir Uygulama. Yayımlanmamış Yüksek Lisans Tezi. Yıldız Teknik Üniversitesi.

Karasar, N. (2006). Bilimsel araştırma yöntemi. Ankara: Nobel Yayınları

Konovsky M. A. (2000).Understanding procedural justice and its impact on business organizations. Journal Of Management 26(3), 489-511

Moorman, R.H. (1991). Relationship between organizational justice and organizational citizenship behavior: Do fairness perceptions influence employee citizenship?.Journal of Applied Psychology, 76, 845-855.

Morrison, E.W. and Milliken, F.J. (2000). Organizational silence: A barrier to change and development in a pluralistic world. Academy of Management Review, 25 (4), 706-725.

Milliken, F. J. Ve Morrison, E. W. (2003). Shades of silence: Emerging themes and future directions for research on silence in organizations. Journal of Management Studies, 40(6), 1563-1568.

Niehoff, B.P. ve Moorman, R.H. (1993). Justice as a mediator of the relationship between methods of monitoring and organizational citizenship behavior, The Academy of Management Journal, 36(3), 527-556.

Özdemir, L. ve Uğur, S. S. (2013). Çalışanların "örgütsel ses ve sessizlik" algılamalarının demografik nitelikler açısından değerlendirilmesi: Kamu ve özel sektörde bir araştırma. Atatürk Üniversitesi İktisadi ve İdari Bilimler Dergisi, 27 (1), 257-281.

Özel Tangirala, S. ve Ramanujam, R. (2008). Employee silence on critical work issues: The cross-level effects of procedural justice climate. Personnel Psychology, 61 (1), 37-68.

Pinder, C.C. and Harlos, K.P. (2001). Employee silence: Quiescence and acquiescence as responses to perceived injustice. Research in Personel and Human Research Management,20, 331-369.

Polat, S. (2007). Ortä̈ğretim Öğretmenlerinin Örgütsel Adalet Algılarl, Örgütsel Güven Düzeyleri İle Örgütsel Vatandaşıı Davranışları Arasındaki İlişki. Basılmamış Doktora Tezi. Kocaeli Üniversitesi Sosyal Bilimler Enstitüsü.

Premaux, S.F. and Bedeian, A.G. (2003). Breaking the silence: The moderating effects of self- monitoring in predicting speaking up in the workplace. Journal of Management Studies, 40 (6), 1537-1562.

Ryan, K. D. and Oestreich, D.K. (1991). Drivingfear out ofthe workplace: How to overcome the invisible barriers to quality, productivity and innovation. San Francisco: Jossey-Bass.

Taşkıran, E. (2011). Liderlik ve örgütsel sessizlik arasındaki etkileşim-örgütsel adaletin rolü. İstanbul: Beta

Van Dyne, L., Ang, S., ve Botero, I.C. (2003). Conceptualizing employee silence and employee voice as multidimensional constructs. Journal of Management Studies, 40(6), 1359-1372.

Yanık, C. (2012). Örgütsel Sessizlik ile Güven Arasındaki İlişki ve Eğitim Örgütlerinde Bir Araştırma. Yayımlanmamış Yüksek Lisans Tezi. Yeditepe Üniversitesi Sosyal Bilimler Enstitüsü. 
Yaman, E. (2007). Üniversitelerde Bir Eğitim Yönetimi Sorunu Olarak Öğretim Elemanının Maruz Kaldı̆̆ı Informal Cezalar: Nitel Bir Araştırma. Yayınlanmamış Doktora Tezi. Marmara Üniversitesi. Eğitim Bilimleri Enstitüsü.

Yaman, E. (2008). Üniversiteler ve etik: Baskılar ya da psikolojik şiddet. İş Ahlâkı,1, 81-98.

Yaman, E. (2009). Yönetim Psikolojisi Açısından İşyerinde Psikoşiddet. Ankara: Nobel.

Yaman, E. (2010). Perception of faculty members exposed to mobbing about the organizational culture and climate. Educational Sciences: Theory \& Practice, 10(1), 547-578.

Yaman, E., Vidinlioğlu, Ö., ve Çitemel, N. (2010). İşyerinde psikoşiddet, motivasyon ve huzur: Öğretmenler çok şey mi bekliyor? Psikoşiddet mağduru öğretmenler üzerine. Uluslararası İnsan Bilimleri, 7(1), 1136- 1151.

Yaman, E., Ruçlar, K. (2014). Örgüt kültürünün yordayıcısı olarak üniversitelerde örgütsel sessizlik. Yükseköğretim ve Bilim Dergisi,1(4),36-50

Yürür, S. (2009). Örgütsel adalet. Çalışma yaşamında davranış. Kocaeli: Umuttepe Yayınları. 


\section{Extended Summary}

Although the consequences of perceived organizational justice and employee's silence has increasingly began to be subject to scientific studies, It has been limited to a few studies which examining together of these independent variables. In this respect, It is expected to contribute to the literature to examine the perceptions of organizational justice and silence behavior of teachers.

The aim of this study is to determine the relationship between perceived organizational justice and level of organizational silence of teachers. While the main subject is examined, sub-problems below have been sought.

1. What is the level of teachers' organizational justice perceptions and organizational silence?

2. Does the teacher's perceived organizational justice and organizational silence level differ according to the variables of sex, age, school, management style which they perceived in the schools they work?

The current study's sample was composed 350 volunteer teacher who are working in Bandırma province of Balıkesir city. In this study, the scale for determining perceived organizational justice developed by Niehoff and Moorman (1993) and adapted by Gürpınar (2006) and the scale for measuring organizational silence level developed by Van Dyne, Ang and Botero (2003) and adapted by Taşkıran (2011) are used. This research is done by using relational survey model. In the analysis of data which procured from scales SPSS 20.0 sofware were utilized.

As a result of the study, perception level for interactional justice is higher than distributive justice and procedural justice and prosocial silence is the highest perceived by teachers, while defensive silence dimension was the at lowest grade evaluated dimension.

Outputs of the research showed that teacher's acquiescent silence has positive and low level relation with distributive, procedural and interactional justice perceptions. Statistically significant relationship was identified only with distributive justice sub-dimension. Their defensive silence has negative, low level and statistically significant relation with procedural and interactional justice perceptions, while having negative, low level and unsignificant relation with distributive justice. In terms of prosocial silence, It has positive, high level and statistically significant relation with procedural and interactional justice perceptions, while having positive, low level and unsignificant relation with distributive justice.

Based on the findings, It is recommended to the school principals to use their authority (awards, missions, responsibilities etc.) fairly, to listen and heed teacher's opinions and reservations during distributive transactions, to act politely, intimate, explicitly and respectful. 